This publication and other Energy Information Administration (EIA) publications may be purchased from the Superintendent of Documents, U.S. Government Printing Office.

\section{All telephone orders should be directed to:}

U.S. Government Printing Office

McPherson Square Bookstore

$1510 \mathrm{H}$ Street, N.W.

Washington, DC 20005

(202)653-2050

FAX (202)376-5055

9 a.m. to 4:30 p.m., eastern time, M-F
Superintendent of Documents

U.S. Government Printing Office

Washington, DC 20402

(202)783-3238

FAX (202)512-2233

8 a.m. to 4 p.m., eastern time, M-F

All mail orders should be directed to:

U.S. Government Printing Office

P.O. Box 371954

Pittsburgh, PA 15250-7954

Complimentary subscriptions and single issues are available to certain groups of subscribers, such as public and academic libraries, Federal, State, local and foreign governments, EIA survey respondents, and the media. For further information and for answers to questions on energy statistics, please contact EIA's National Energy Information Center. Address, telephone numbers, and hours are as follows:

National Energy Information Center, EI-231

Energy Information Administration

Forrestal Building, Room 1F-048

Washington, DC 20585

(202)586-8800

Internet E-Mail: INFOCTR@ EIA.DOE.GOV

TTY: For people who are deaf or hard

of hearing: (202)586-1181

9 a.m. to 5 p.m., eastern time, M-F

Released for Printing: July 5, 1995 
DOE/EIA-0570(94)

Distribution Category UC-950

\title{
Uranium Purchases Report 1994
}

\author{
July 1995
}

Energy Information Administration

Office of Coal, Nuclear, Electric and Alternate Fuels

U.S. Department of Energy

Washington, DC 20585 


\section{Preface}

This report is the third in a series of annual publications by the Energy Information Administration required by the Energy Policy Act of 1992 (EPACT 1992), Public Law 102-486 (October 24, 1992), Subtitle B, 42 USC § 2296b-4 Section 1015 of P.L. 102-486, which provides that:

... the owner or operator of any civilian nuclear power reactor shall report to the Secretary (of Energy), acting through the Administrator of the Energy Information Administration, for activities of the previous fiscal year-

(1) the country of origin and the seller of any uranium or enriched uranium purchased or imported into the United States either directly or indirectly by such owner or operator; and

(2) the country of origin and the seller of any enrichment services purchased by such owner or operator.

This information is required to be made available to the Congress annually. Data reported by domestic nuclear utility companies in their responses to the 1991 through 1994 "Uranium Industry Annual Survey," Form EIA-858, Schedule B,"Uranium Marketing Activities," are provided in response to the requirements in the EPACT 1992.
The Appendix contains an explanation of Form EIA-858 survey methodologies with emphasis on the processing of Schedule B data.

Information published in this report are U.S. utility purchases of uranium and enrichment services by origin country and seller. Also, this report contains a glossary of terms and additional purchase information covering average price and contract duration.

This report was prepared in the Office of Coal, Nuclear, Electric and Alternate Fuels by the Analysis and Systems Division. General information regarding this publication may be obtained from John Geidl (202/254-5570), Director, Office of Coal, Nuclear, Electric and Alternate Fuels: Robert M. Schnapp (202/254-5392), Director, Analysis and Systems Division; or Z. D. Nikodem (202/254-5550), Branch Chief, Nuclear Fuel Cycle Branch. Specific questions regarding the preparation and content of this report should be directed to the following:

Doug Bonnar on 202/254-5560

Dbonnar@ @IA.DOE.GOV

or

Charles Johnson on 202/254-5568

Cjohnson @ EIA.DOE.GOV. 


\section{Uranium Purchases Report 1994}

\section{Uranium Purchases by U.S. Utilities}

During 1994, the owners and operators of U.S. civilian nuclear electric generating units took delivery of 38.3 million pounds $\mathrm{U}_{3} \mathrm{O}_{8}$ equivalent $\left(\mathrm{U}_{3} \mathrm{O}_{8} \mathrm{e}\right)$ under purchase contracts from suppliers (Table 1 ). Of the delivered total of 38.3 million pounds, natural uranium ${ }^{1}$ accounted for 35.7 million pounds (93 percent) and enriched uranium accounted for 2.6 million pounds ( 7 percent). The 31 firms that supplied the uranium to the utilities under these contracts are shown in the following list. Twelve of the 31 firms (designated with an asterisk) made deliveries under new purchase contracts in 1994.

\section{Uranium Sellers to U.S. Utilities}

Albuquerque Uranium Corporation

B \& W Fuel Company

British Nuclear Fuel Ltd. (BNFL)*

Cameco Corporation*

China Nuclear Energy Industry Corp. (CNEIC)

COGEMA, Inc.

Energy Fuels Exploration Company

Energy Fuels Corporation*

Energy Fuels Limited

Energy Resources of Australia*

Everest Exploration, Inc.

Geomex Minerals, Inc.*

Global Nuclear Supply Service Ltd.*

Malapai Resources Company

Nuexco Trading Corporation*

NUKEM, Inc.*

Olympic Dam Corporation

Pathfinder Mines Corporation

Power Resources, Inc.

R \& D Energy Resources*

Rio Grande/Nuclear Fuels

RTZ Minerals Services Limited

Sheep Mountain Partners

Siemens Nuclear Power Corporation

Total Minerals Corporation

U.S. Energy Corporation
UG U.S.A., Inc.*

Uranerz Exploration \& Mining Ltd.*

Urangesellschaft $\mathrm{Mbh}$

Uranium Resources, Inc.*

Westinghouse Electric Corporation

Of the 38.3 million pounds $\mathrm{U}_{3} \mathrm{O}_{8} \mathrm{e}$ delivered to U.S. utilities in 1994, deliveries under spot-contract purchases accounted for 8.5 million pounds at an average price of $\$ 9.01$ per pound; short-term contract purchases totaled 4.5 million pounds at an average price of $\$ 8.14$ per pound; medium-term contract purchases accounted for 9.4 million pounds at an average price of $\$ 9.84$ per pound; and long-term contract purchases totaled 15.8 million pounds at an average price $\$ 12.13$ per pound. Some long-term contracts were signed in the 1970's. ${ }^{2}$

Of the 38.3 million pounds $\mathrm{U}_{3} \mathrm{O}_{8} \mathrm{e}$ delivered to U.S. utilities in 1994 at an average price of $\$ 10.40$ per pound, 7.7 million pounds ( 20 percent) were of U.S. origin at an average price of $\$ 12.08$ per pound. Non-U.S. origin uranium accounted for 30.6 million pounds ( 80 percent) of the deliveries at an average price of $\$ 9.97$ per pound. Some of this material was in the United States and not imported in 1994. The top seven origin countries in descending order by quantity for non-U.S. origin uranium are shown in the list below.

\begin{tabular}{lc}
$\begin{array}{c}\text { Top Seven Non-U.S. } \\
\text { Origin Countries }\end{array}$ & $\begin{array}{c}\text { Average Price } \\
\left(\$ \text { per } \mathrm{Ib} . ~_{3} \mathrm{O}_{8} \mathrm{e}\right)\end{array}$ \\
\hline Canada & 10.49 \\
Uzbekistan & 8.35 \\
Australia & 9.88 \\
Kazakhstan & 8.94 \\
Russia & 8.81 \\
China & 9.56 \\
South Africa & 9.64
\end{tabular}

\footnotetext{
'Natural uranium is uranium concentrate $\left(\mathrm{U}_{3} \mathrm{O}_{8}\right)$ and uranium hexafluoride $\left(\mathrm{UF}_{6}\right)$.

${ }^{2}$ Spot contract-A one-time delivery of the entire contract quantity to occur within 1 year of contract execution. Short-term-contract-One or more deliveries to occur over a period of less than 3 years following contract execution. Medium-term contract-One or more deliveries to occur over a period of 3 to 6 years following contract execution. Long-term contract-One or more deliveries to occur after a period of a least 6 years following contract execution.
} 


\begin{tabular}{|c|c|c|c|c|}
\hline \multirow[b]{2}{*}{ Origin Country } & & \multicolumn{3}{|c|}{ Deliveries } \\
\hline & & $\begin{array}{c}\text { Uranium } \\
\text { Purchases from } \\
\text { Suppliers } \\
\text { (thousand pounds } \\
\mathrm{U}_{3} \mathrm{O}_{8} \text { equivalent) } \\
\end{array}$ & $\begin{array}{l}\text { Enrichment Feed } \\
\text { (thousand pounds } \\
\mathrm{U}_{3} \mathrm{O}_{8} \text { equivalent) }\end{array}$ & $\begin{array}{c}\text { Separative Work } \\
\text { Units } \\
\text { (thousand SWU) }\end{array}$ \\
\hline Total .... & & 38,281 & 37,608 & 9,197 \\
\hline By origin country: $\ldots \ldots \ldots \ldots$ & Australia & 2,812 & 2,880 & -- \\
\hline & Brazil & W & w & -- \\
\hline & Canada & 14,613 & 14,868 & -- \\
\hline & China & 1,696 & 1,429 & $237^{\mathrm{a}}$ \\
\hline & France & W & w & $549^{b}$ \\
\hline & Gabon & W & w & -- \\
\hline & Germany & W & w & $w^{c}$ \\
\hline & Mongolia & $W$ & w & -- \\
\hline & Namibia & 796 & 804 & -- \\
\hline & Netherlands & -- & -- & $W^{d}$ \\
\hline & NIS $^{e}$ Total & 8,665 & 6,308 & -- \\
\hline & Kazakhstan & 2,777 & 3,470 & -- \\
\hline & Kyrgyzstan & W & w & -- \\
\hline & Russia & 1,779 & 1,764 & $421^{\prime}$ \\
\hline & Tajikistan & $w$ & 0 & - \\
\hline & Ukraine & $w$ & $w$ & -- \\
\hline & Uzbekistan & 3,550 & 715 & -- \\
\hline & South Africa & 1,106 & 1,195 & $0^{9}$ \\
\hline & Spain & 0 & $w$ & -- \\
\hline & United Kingdom & $w$ & $w$ & $w^{h}$ \\
\hline & United States & 7,718 & 8,522 & $7,521^{i}$ \\
\hline
\end{tabular}

a CNEIC (China Nuclear Energy Industry Corp.) enrichment plant, Lanzhou Province, Peoples Republic of China.

burodif enrichment plant, Georges Besse, France.

c Urenco enrichment plant, Gronau, Germany.

-Urenco enrichment plant, Almelo, Netherlands.

NIS = Newly Independent States

'Techsnabexport (Tenex) enrichment plants, Angarsk, Russia; Ekaterinburg, Russia; Krasnoyarsk, Russia; and Tomsk, Russia.

IAEC (Atomic Energy Corporation of South Africa, Ltd.) enrichment plant, Valindaba, South Africa.

h Urenco enrichment plant, Capenhurst, United Kingdom.

' USEC enrichment plants, Paducah, Kentucky and Portsmouth, Ohio.

$W=$ Witheld to avoid disclosure of company identifiable data.

$-=$ Not applicable.

Note: Totals may not equal sum of components because of independent rounding.

Source: Energy Information Administration, Form EIA-858, "Uranium Industry Annual Survey"(1094).

U.S. utilities signed 58 new purchase contracts in 1994. The quantity of uranium delivered in 1994 under 40 of the 58 new contracts was 10.7 million pounds $\mathrm{U}_{3} \mathrm{O}_{8}$ e with an average price of $\$ 8.81$ per pound. The remaining 18 are new contracts with deliveries that started after 1994.
In 1994, deliveries associated with new purchase contracts accounted for 28 percent of total deliveries. In 1994, imports accounted for 15.5 million pounds $\mathrm{U}_{3} \mathrm{O}_{8} \mathrm{e}$ or 41 percent of total deliveries to utilities, compared with 33 and 50 percent in 1992 and 1993 respectively (Table 2). 
Table 2. Uranium Purchases by U.S. Utilities, 1991-1994 (Thousand Pounds $\mathrm{U}_{3} \mathrm{O}_{8}$ Equivalent)

\begin{tabular}{|c|c|c|c|c|c|}
\hline \multirow[b]{2}{*}{ Category } & & \multicolumn{4}{|c|}{ Deliveries } \\
\hline & & 1991 & 1992 & 1993 & 1994 \\
\hline \multicolumn{2}{|c|}{ 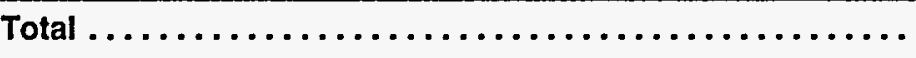 } & 40,947 & 35,383 & 31,184 & 38,281 \\
\hline \multicolumn{2}{|c|}{ Deliveries Under Domestic Purchases (Non-Imports) a . . . . } & 26,812 & 23,572 & 15,511 & 22,745 \\
\hline By material type: . . . . . . . . . . . & $\begin{array}{l}\text { Natural } \mathrm{U}_{3} \mathrm{O}_{8} \\
\text { Natural UF } \\
\text { Enriched UF }\end{array}$ & $\begin{array}{r}17,011 \\
7,458 \\
2,343\end{array}$ & $\begin{array}{r}17,847 \\
3,180 \\
2,546\end{array}$ & $\begin{array}{r}13,024 \\
2,198 \\
289\end{array}$ & $\begin{array}{r}15,150 \\
5,498 \\
2,097\end{array}$ \\
\hline \multirow{10}{*}{ By origin country: $\ldots \ldots \ldots \ldots \ldots$} & Australia & 1,374 & $w$ & 737 & 1,297 \\
\hline & Canada & 2,943 & 5,347 & 4,219 & 4,622 \\
\hline & China & 1,146 & 920 & 2,127 & 1,616 \\
\hline & Namibia & 917 & 1,333 & 0 & 425 \\
\hline & Portugal & W & $w$ & 0 & 0 \\
\hline & $\begin{array}{c}\text { NIS Total } \\
\text { Kazakhstan } \\
\text { Kyrgyzstan } \\
\text { Russia } \\
\text { Tajikistan } \\
\text { Uzbekistan }\end{array}$ & $\begin{array}{r}6,824^{c} \\
\text { NA } \\
\text { NA } \\
\text { NA } \\
\text { NA }\end{array}$ & $\begin{array}{r}5,831^{c} \\
\text { NA } \\
\text { NA } \\
\text { NA } \\
\text { NA }\end{array}$ & $\begin{array}{r}3,163 \\
W \\
W \\
2,285 \\
0 \\
587\end{array}$ & $\begin{array}{r}5,327 \\
976 \\
w \\
762 \\
w \\
3,223\end{array}$ \\
\hline & South Africa & 0 & 349 & $w$ & 1,106 \\
\hline & Spain & $w$ & 0 & 0 & W \\
\hline & United Kingdom & $w$ & 0 & $w$ & 281 \\
\hline & United States & 12,443 & 7,934 & 3,896 & 7,718 \\
\hline \multirow{8}{*}{ By origin country: $\ldots \ldots \ldots \ldots \ldots$} & $\begin{array}{l}\text { Brazil } \\
\text { Canada }\end{array}$ & & & $\begin{array}{r}0 \\
9,800\end{array}$ & $\begin{array}{r}W \\
9,991\end{array}$ \\
\hline & China & $w$ & $w$ & 795 & 80 \\
\hline & Gabon & $w$ & $w$ & 0 & $w$ \\
\hline & Germany & $w$ & $w$ & $w$ & 0 \\
\hline & Mongolia & 0 & 0 & w & 0 \\
\hline & Namibia & 0 & $w$ & 392 & 371 \\
\hline & $\begin{array}{c}\text { NIS }{ }^{b} \text { Total } \\
\text { Kazakhstan } \\
\text { Kyrgyzstan } \\
\text { Russia } \\
\text { Ukraine } \\
\text { Uzbekistan }\end{array}$ & $\begin{array}{l}W^{c} \\
\text { NA } \\
\text { NA } \\
\text { NA } \\
\text { NA }\end{array}$ & $\begin{array}{r}1,123^{c} \\
N A \\
\text { NA } \\
\text { NA } \\
\text { NA }\end{array}$ & $\begin{array}{r}3,067 \\
w \\
w \\
1,420 \\
0 \\
w\end{array}$ & $\begin{array}{r}3,338 \\
1,801 \\
w \\
1,017 \\
w \\
327\end{array}$ \\
\hline & $\begin{array}{l}\text { South Africa } \\
\text { United Kingdom }\end{array}$ & $\begin{array}{l}0 \\
0\end{array}$ & $\begin{array}{r}W \\
0\end{array}$ & $\begin{array}{c}0 \\
w\end{array}$ & $\begin{array}{l}0 \\
0\end{array}$ \\
\hline
\end{tabular}

\footnotetext{
"U.S. utilities reported whether that year's delivery involved importation. If not, the importation of non-U.S. origin uranium was conducted in a previous year. The total quantity of deliveries shown for 1991 through 1994 represents, for each year, the sum for non-import and import purchased deliveries. ${ }^{\mathrm{D}} \mathrm{NIS}=$ Newly Independent States.

"The name "Russia" was used to report data for 1991 and 1992. No further breakdown into the newly formed, separate Republics, known now as the Newly Independent States, was available.

$W=$ Withheld to avoid disclosure of company identifiable data. $N A=$ Not available. Note: Totals may not equal sum of components because of independent rounding. Source: Energy Information Administration, Form ElA-858, "Uranium Industry Annual Survey."
} 


\section{Uranium Enrichment Feed}

In 1994, utility enrichment feed deliveries by U.S. utilities totaled 37.6 million pounds $\mathrm{U}_{3} \mathrm{O}_{8} \mathrm{e}$ shipped to both domestic and foreign enrichment suppliers, 7 percent above the 1993 level (Table 1). Deliveries consisted of 8.5 million pounds ( 23 percent) of U.S. origin and 29.1 million pounds ( 77 percent) of non-U.S. origin uranium. For non-U.S. origin uranium, the top five origin countries in descending order were Canada (51 percent), Kazakhstan (12 percent), Australia (10 percent), Russia (6 percent), and China (5 percent). The remaining 16 percent of the non-U.S. origin uranium delivered to enrichment plants was from Brazil, France, Gabon, Germany, Mongolia, Namibia, Kyrgyzstan, Ukraine, Uzbekistan, South Africa, Spain, and the United Kingdom. Utilities took delivery of 35.7 million pounds natural uranium under purchase contracts in 1994, and the additional 1.9 million pounds of enrichment feed came from inventory withdrawals or deliveries by other transactions such as exchanges or loans. Utility enrichment feed deliveries to U.S. enrichers in 1994 totaled 33.5 million pounds $\mathrm{U}_{3} \mathrm{O}_{8} \mathrm{e}$ ( 89 percent of total deliveries). Feed deliveries to non-U.S. enrichers in 1994 totaled 4.1 million pounds $\mathrm{U}_{3} \mathrm{O}_{8} \mathrm{e}$ (11 percent of total deliveries) (Table 3).

\section{Enrichment Services Purchased by U.S. Utilities}

The amount of separative work units (SWU) purchased by U.S. utilities under enrichment service contracts that were delivered in 1994 was 9.2 million SWU (Table 1). The 10 firms that were named as the sellers of enrichment services for these SWU deliveries in 1994 are shown in the following list.

\author{
Enrichment Service Sellers to U.S. Utilities \\ B \& W Fuel Company \\ COGEMA, Inc. \\ Global Nuclear Supply Service, Ltd. \\ Nuexco Trading Corporation \\ NUKEM, Inc. \\ Siemens Nuclear Power Corporation \\ UG U.S.A., Inc. \\ Uranium Exchange Company \\ United States Enrichment Corporation (USEC) \\ Urenco
}

Eighty-two percent of the enrichment was conducted at U.S. enrichment plants under the United States Enrichment Corporation operation. The remaining enrichment for U.S. utilities was performed by CNEIC, Eurodif, Tenex, and Urenco. ${ }^{6}$

\footnotetext{
${ }^{6}$ CNEIC (China Nuclear Energy Industry Coporation), Peoples Republic of China. Eurodif, a consortium of Cogema, 37 percent ; Sofidif, 25 percent (Cogima 60 percent and OIAETI (Iman) 40 percent); Synatom (Belgium) and Enusa (Spain), 11 percent each; and ENEA and AGIP (both Italy), 8 percent each, operates the Georges Besse gaseous diffusion plant at the Tricastin site in France. Cogema handles sales and marketing of Eurodif products and services, excluding sales to Eurodif partners. Tenex (Techsnabexport) utilizes four gas centrifuge technology plants at Ekaterinburg, Angarsk, Krasnoyarsk, and Tomsk in Russia. The four plants are owned by The Ministry of Atomic Energy of the Russian Federation (Minatom). Urenco is a consortium created by treaty between Germany, the Netherlands, and the United Kingdom. Urenco, Ltd., is the holding company for gas centrifuge plants located at three wholly-owned subsidiaries: Urenco (NL). Almelo. The Netherlands; Urenco (D), Gronau, Germany; and Urenco (UK). Capenhurst, United Kingdom. British Nuclear Fuels plc (BNFL), in the United Kingdom, Ultra-Centrifuge Nederland N.V. (UCN) in the Netherlands, and Uranit Gmbh in Germany are equal shareholders in Urenco, Ltd.
} 
Table 3. U.S. Utility Enrichment Feed Deliveries, 1991 - 1994

(Thousand Pounds $\mathrm{U}_{3} \mathrm{O}_{8}$ Equivalent)

\begin{tabular}{|c|c|c|c|c|c|}
\hline \multirow[b]{2}{*}{ Category } & & \multicolumn{4}{|c|}{ Deliveries } \\
\hline & & 1991 & 1992 & 1993 & 1994 \\
\hline \multicolumn{2}{|c|}{ Enrichment Feed Deliveries (Total) ${ }^{\mathrm{a}} \ldots \ldots \ldots \ldots \ldots$} & 37,992 & 32,045 & 35,100 & 37,608 \\
\hline \multicolumn{2}{|c|}{ TO U.S. DOEJUSEC (Total) ${ }^{b} \ldots \ldots \ldots \ldots \ldots \ldots \ldots$} & 33,852 & 27,622 & 32,362 & 33,498 \\
\hline \multicolumn{2}{|l|}{ U.S. Origin Uranium (Total) } & 11,711 & 9,077 & $\mathbf{7 , 7 3 1}$ & 8,471 \\
\hline \multicolumn{2}{|c|}{ Non-U.S. Origin Uranium (Total) . . . . . . . . . . . } & 22,141 & 18,545 & 24,631 & 25,027 \\
\hline \multirow{18}{*}{ By origin country: .......... } & Australia & 2,641 & 1,784 & 1,463 & 2,880 \\
\hline & Brazil & 0 & 0 & 0 & w \\
\hline & Canada & 11,327 & 8,984 & 11,168 & 13,870 \\
\hline & China & $w$ & $w$ & w & 1,379 \\
\hline & France & $w$ & W & $w$ & w \\
\hline & Gabon & $w$ & W & $w$ & $w$ \\
\hline & Germany & 0 & 0 & $w$ & $w$ \\
\hline & Mongolia & 0 & 0 & 0 & $w$ \\
\hline & Namibia & $w$ & $w$ & 735 & 804 \\
\hline & NIS ${ }^{c}$ Total & $3,176^{d}$ & $5,146^{d}$ & 5,748 & 3,373 \\
\hline & Kazakhstan & NA & NA & 457 & 2,041 \\
\hline & Kyrgyzstan & NA & NA & 0 & 0 \\
\hline & Russia & NA & NA & 5,072 & 992 \\
\hline & Uzbekistan & NA & NA & 0 & 340 \\
\hline & Portugal & 0 & $w$ & 0 & 0 \\
\hline & South Africa & $w$ & 662 & 1,123 & 1,119 \\
\hline & Spain & 0 & 0 & $w$ & W \\
\hline & United Kingdom & $w$ & $w$ & $w$ & $w$ \\
\hline \multicolumn{2}{|l|}{ To Non-U.S. Enrichers (Total) ${ }^{\ominus}$. } & 4,140 & 4,423 & 2,738 & 4,110 \\
\hline \multicolumn{2}{|l|}{ U.S. Origin Uranium (Total) } & 2,120 & 1,048 & 55 & 51 \\
\hline \multicolumn{2}{|l|}{ Non-U.S. Origin Uranium (Total) } & 2,020 & 3,375 & 2,683 & 4,059 \\
\hline
\end{tabular}

\footnotetext{
${ }^{a}$ The total quantity of Utility Enrichment Feed Deliveries shown for 1991 through 1994 represents, for each year, the sum of materials shipped for enrichment to United States Department of Energy (USDOE) and/or United States Enrichment Corporation (USEC), and to Non-U.S. Enrichers.

'The total quantity for 1991 through 1994 shipped to USDOE or USEC represents, for each year, the sum of U.S. Origin Uranium and Non-U.S. Origin Uranium.

CNIS = Newly Independent States.

"The name "Russla" was used to report data for 1991 and 1992. No further breakdown into the newly formed, separate Republics, known now as the Newly Independent States, was available.

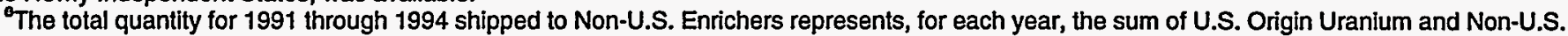
Origin Uranium.

$W=$ Withheld to avoid disclosure of company identifiable data. NA = Not available.

Note: Totals may not equal sum of components because of independent rounding.

Source: Energy Information Administration, Form EIA-858, "Uranium Industry Annual Survey."
} 


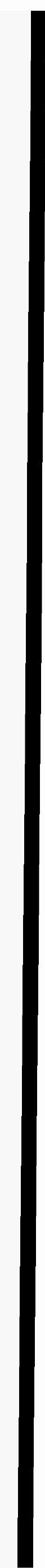




\section{Appendix}

\section{Survey Methodology}

\section{Survey Design}

Form EIA-858, "Uranium Industry Annual Survey," was used to collect information from all companies known or believed to have been involved in the U.S. uranium industry during 1994. Included in this survey are domestic utilities that own and/or operate nuclear power reactors. The 1994 survey form was mailed to respondents in January 1995, and was due back in March 1995. Respondents to the "Uranium Industry Annual Survey" were asked to provide data current to the end of 1994 about their Uranium Raw Materials Activities (Schedule A) and Uranium Marketing Activities (Schedule B).

In particular, Schedule B covers: uranium transaction parameters including name of the other party; type of transaction; uranium materials covered; origin for the uranium materials, conversion and enrichment services, delivery destination; importation and exportation; pricing mechanism; schedule of uranium deliveries with corresponding prices; uranium inventories; materials shipped for enrichment; projected enrichment feed deliveries; unfilled market requirements; and the amount of enrichment services and loaded fuel assemblies by U.S. utilities. Quantities of uranium reported are as equivalent $\mathrm{U}_{3} \mathrm{O}_{8}$ rounded to the nearest thousand pounds.

The data collected on Form EIA-858 are subject to several sources of error. These sources are: (1) coverage (the respondent frame might not be complete or, on the other hand, there might be double counting); (2) nonresponse (all units surveyed might not respond or might not provide all the information requested); (3) respondents (respondents might commit errors in reporting the data); (4) processing (the data collection agency might omit or incorrectly transcribe a submission); (5) concept (the data collection elementsmight not measure the items they were intended to measure); and (6) adjustments (errors might be made in estimating values for missing data).

Because the "Uranium Industry Annual Survey" is a universe survey rather than a sample survey, sampling errors do not affect the data provided in this report. ${ }^{7}$ Although it is not possible to present estimates of nonsampling error, precautionary steps were taken at each stage of the survey design and operation to minimize the possible occurrence of these errors. These steps are described below, and the errors they were designed to minimize are named (in parenthesis).

\section{Survey Universe/Frame (Coverage Errors)}

The survey universe includes all nuclear utilities involved in the U.S. uranium industry. The criteria for responding to Schedule B are firms that during 1994: (1) held existing contracts covering the sale, purchase, exchange, loan, loan repayment, or custody of uranium or entered into similar new contracts; (2) held inventories of uranium in any form excluding reactor-inserted, fabricated fuel; (3) maintained an uranium-inventory policy; (4) made actual deliveries of uranium feed materials to any enrichment supplier; and/or (5) purchased enrichment services.

The respondent list used for the Form EIA-858 survey was developed from a frame of all establishments known to meet the selection criteria. The frame of potential respondents was compiled from previous surveys and from information in the public domain. As it specifically relates to Schedule $B$, the frame was intended to cover the following: all utilities owning nuclear-fueled generating stations, fuel converters and fabricators, and utilities with whole or partial ownership in operating or planned uranium-fueled power plants.

\footnotetext{
${ }^{7}$ Sampling error is a measure of the variation that occurs by chance because a sample rather than a complete enumeration of units is surveyed.
} 


\section{Survey Procedures (Nonresponse)}

The survey forms were sent by first class mail to ensure their receipt only by the proper respondent organization. If the U.S. Postal Service was unable to deliver the survey form, the corrected address was obtained where possible. All nuclear utilities currently conducting business in the U.S. uranium industry were contacted during this survey.

The Form EIA-858 is a self-administered questionnaire requesting data about many areas of company operations. The scope of the questions is necessarily broad, and selfreporting of company-specific data are required.

Cooperation from industry on the 1994 survey was, as in previous years, excellent. A large number of respondents returned the completed form within the specified deadlines. Those that had not responded by the due dates were telephoned to encourage submission of the forms, and those calls resulted in the submission of most of the remaining forms. In addition, a followup letter was mailed to nonres- pondents requesting compliance with the survey. Subsequently, telephone calls were made to obtain forms not yet submitted. In some instances, company data were modified/collected through telephone conversations made to clarify items reported/omitted on their submissions. To reduce the reporting burden on the respondents, data for contracts and selected other data elements from the prior year's survey form were preprinted on each respondent's 1994 survey.

\section{Data Editing, Analysis, and Processing (Respondent and Processing Errors)}

The survey forms were logged in and reviewed by agency personnel prior to data entry into the Uranium Industry Annual System, an automated data base containing all current and historical data from each company's submission. The data base is maintained on the EIA computer facility in Washington, DC. After entry into the data base, a copy of each Schedule B was distributed to the Analysis and Systems Division analyst for review and approval. The submissions were checked for internal consistency, and the reported data were compared with previous collections of similar data. After reviewing the submissions, the analyst consulted with the reporting company, as needed, to resolve data problems and to confirm any corrections of the data. Data areas that were reviewed and the corrections that were made differed from company to company. Most represented differing interpretations of the data item definitions. Computer edits were also used to identify keypunch errors, out-of-range values, and unlikely data combinations. These edits either were corrected to represent the data reported on the submissions or were changed only after confirming the corrected values by telephone conversations with company representatives. Data coding and entry errors were eliminated by proofing data after entry. All changes to data were documented.

\section{Response Rates}

Schedule B of Form EIA-858 was mailed to 89 firms and to the Office of Uranium Programs (NE-30), U.S. Department of Energy, and to the United States Enrichment Corporation (USEC). All of the schedules that were mailed to nuclear utilities, to NE-30, and to USEC were returned (100 percent response) with information as requested on the form. Of course, not all Schedule B data items were applicable to each responding utility, to NE30 , or to USEC.

\section{Missing Data}

Omissions of data identified during the prescreening and editing of the data fell into two categories: (1) data that were withheld because of contractual constraints, or (2) because particular data were unknown. Respondents were contacted regarding omissions to verify that the data could not be reported. Only confirmed company data are contained in the data base and included in this report.

\section{Nondisclosure of Data}

To protect the confidentiality of individual respondents' data, a policy was implemented to ensure that the reporting of survey data in this report would not associate those data with a particular company. This policy is in compliance with EIA Standard No. 88-05-06, "Nondisclosure of Company Identifiable Data in Aggregate Cells." In tables where the nonzero value of a cell is composed of data from fewer than three companies or if a single company dominates a table-cell value so that the reporting of the value would lead to identification of a company's data, then the EIA classifies the cell value as "sensitive," and the cell value is withheld ("W") from the report. Within a table with a sensitive cell value, selected values in other cells of the table are also withheld, as necessary, so that the sensitive cell value cannot be computed using the values in published cells. 


\section{Glossary}

Enrichment Feed Deliveries: Uranium that is shipped under contract to a supplier of enrichment services for use in preparing enriched uranium product to a specified ${ }^{235} \mathrm{U}$ concentration and that ultimately will be used as fuel in a nuclear reactor.

\section{Enrichment Services: See Separative Work Units (SWU).}

Price: The quantity-weighted average of the prices paid for deliveries of uranium purchases.

Purchases of Uranium: The amount of uranium material that is delivered during a survey year as reported on the Form EIA-858, "Uranium Industry Annual Survey" (UIAS), as purchases of either uranium ore, $\mathrm{U}_{3} \mathrm{O}_{8}$, natural $\mathrm{UF}_{6}$, or enriched $\mathrm{UF}_{6}$. The amount of uranium material under other types of contracts reported on the UIAS, i.e., loans and exchanges, is excluded.

Separative Work Units (SWU): The standard measure of enrichment services. The effort expended in separating a mass $F$ of feed of assay $x$ into a mass $P$ of product assay $\mathrm{xp}$ and waste of mass $\mathrm{W}$ and assay $\mathrm{xw}$ is expressed in terms of the number of separative work units needed, given by the expression $S W U=W V(x w)+P V(x p)$ $F V(x f)$, where $V(x)$ is the "value function," defined as $V(x)=(1-2 x) \ln ((1-x) / x)$.
Uranium: A heavy, naturally radioactive, metallic element (atomic number 92). Its two principally occurring isotopes are ${ }^{235} \mathrm{U}$ and ${ }^{238} \mathrm{U}$. The isotope ${ }^{235} \mathrm{U}$ is indispensable to the nuclear industry because it is the only isotope existing in nature to any appreciable extent that is fissionable by thermal neutrons. The isotope ${ }^{238} \mathrm{U}$ is also important because it absorbs neutrons to produce a radioactive isotope that subsequently decays to the isotope ${ }^{239} \mathrm{Pu}$, which also is fissionable by thermal neutrons.

o Concentrate: A yellow or brown powder produced from naturally occurring uranium minerals as a result of milling uranium ore or processing uraniumbearing solutions. Synonymous with yellowcake, $\mathrm{U}_{3} \mathrm{O}_{8}$, or uranium oxide.

o Enriched Uranium: Uranium in which the ${ }^{235} \mathrm{U}$ isotope concentration has been increased to greater than the 0.711 percent ${ }^{235} \mathrm{U}$ (by weight) present in natural uranium.

o Uranium Hexafluoride $\left(\mathrm{UF}_{6}\right)$ : A white solid obtained by chemical treatment of $\mathrm{U}_{3} \mathrm{O}_{8}$, which forms a vapor at temperatures above 56 degrees Centigrade. $\mathrm{UF}_{6}$ is the form of uranium required for the enrichment process.

Uranium Oxide: Uranium concentrate or yellowcake. Abbreviated as $\mathrm{U}_{3} \mathrm{O}_{8}$. 


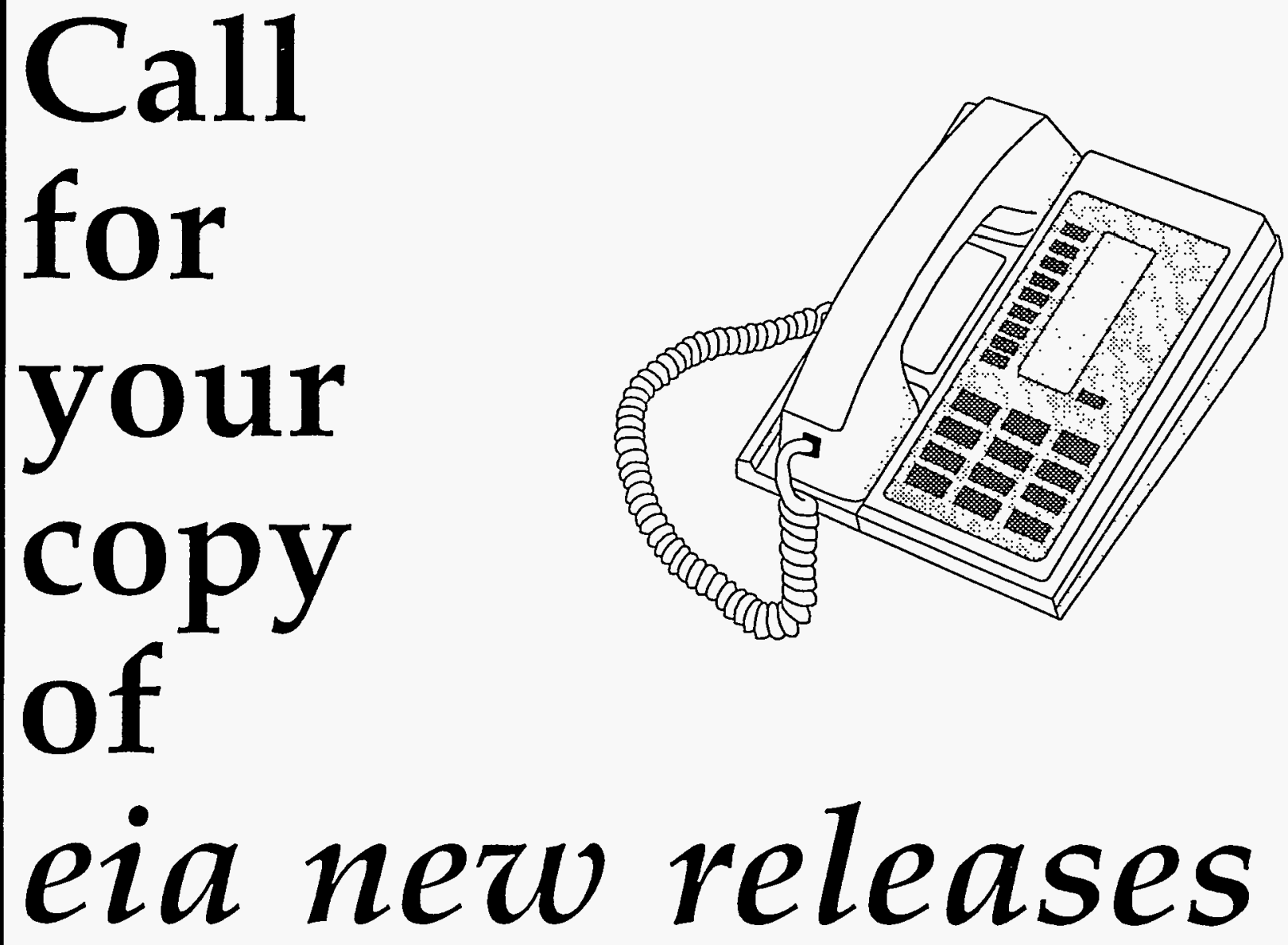

A concise and timely review of new statistical publications and energy news

Offered from the National Energy Information Center

For a complimentary copy of this bimonthly bulletin, or a complimentary subscription, call (202)586-8800. 
Energy Information Administration

U.S. Department of Energy

Forrestal Building, El-231

Washington, DC 20585

OFFICIAL BUSINESS

PENALTY FOR PRIVATE USE, $\$ 300$
FIRST-CLASS MAIL POSTAGE \& FEES PAID U.S. DEPT OF ENERGY

PERMIT NO. G-765 